\title{
Naturally suppressed apoptosis prevents follicular atresia and oocyte reserve decline in the adult ovary of Lagostomus maximus (Rodentia, Caviomorpha)
}

\author{
Federico Jensen, Miguel A Willis, Mirta S Albamonte, María B Espinosa and Alfredo D Vitullo \\ Centro de Estudios Biomédicos, Biotecnológicos, Ambientales y Diagnóstico (CEBBAD), Universidad Maimónides, \\ Hidalgo 775, C1405BCK Buenos Aires, Argentina
}

Correspondence should be addressed to A D Vitullo; Email: vitullo.alfredo@maimonides.edu

\begin{abstract}
It has been widely accepted that mammalian females are born with a non-renewing, finite pool of oocytes that will be continuously cleared by atresia, with only a small proportion of them reaching ovulation. Apoptosis regulates this mass germ cell death, especially through the balance between pro- and anti-apoptotic proteins encoded by the $B C L-2$ gene family. The caviomorph rodent Lagostomus maximus, the South American plains viscacha, displays the highest ovulation rate known for a mammal releasing 400-800 eggs per cycle. We tested the hypothesis that in $L$. maximus massive polyovulation is a consequence of reduced apoptosis resulting in suppressed follicular atresia. We found that anti-apoptotic BCL-2 gene is markedly expressed in all kind of follicles from primordial to fully mature antral stages in the adult ovary of $L$. maximus. On the other hand, pro-apoptotic $B A X$ gene showed weak signals or was undetectable by immunohistochemical examination. Western blot against both proteins confirmed immunohistochemical results. Screening for DNA fragmentation by TUNEL assay was conspicuously negative in ovaries from both pregnant and non-pregnant females. In addition, $\alpha$-oestrogen receptor also showed an enhanced expression from primordial stage to fully mature antral follicles. Our results show that natural preferential expression of $B C L-2$ and restricted $B A X$ expression greatly suppresses apoptosis in the ovary of $L$. maximus. This prevents the decline of the oocyte reserve by abolishing follicular atresia and enables the highest ovulation rate known for a mammal, 400-800 or more eggs per cycle. Reproduction (2006) 132 301-308
\end{abstract}

\section{Introduction}

Early in mammalian foetal life, primordial germ cells (PGC) migrate to the genital ridges, proliferate giving rise to large numbers of oogonia, and finally enter meiosis producing by birth, a pool of oocytes arrested at the diplotene stage of the first meiotic division (Hirshfield 1991). As meiosis progresses, somatic cells surround the oocytes and folliculogenesis will dominate the different periods of late foetal, juvenile and adult life (Hirshfield 1991). Once PGC differentiate to enter meiosis folliculogenesis, a degenerative process classically referred to as atresia will continuously clear them (Kaipia \& Hsueh 1997). In the rat, germ cells undergo attrition since they enter meiosis, and four waves of atresia take place during foetal development being responsible for the loss of almost $77 \%$ of the original pool, by $48 \mathrm{~h}$ after birth (Hirshfield 1991). In the laboratory mouse, $66 \%$ of the original oogonia are lost by the end of gestation (Flaws et al. 2001). In humans, the process of oocyte loss is particularly dramatic; of $7 \times 10^{6}$ potential oocytes in a 20 -week-old foetus, around $85 \%$ are already lost by birth, and more than 99\% will be lost by the beginning of puberty (Baker 1963, Forabosco et al. 1991). This mass germ cell death lies on the genetic machinery of apoptosis, programmed cell death (PCD) (Hsueh et al. 1996, Tilly 1996). Although genes involved in PCD are numerous, the majority of studies of ovarian germ cell demise in mammals have shown that the expression of $B C L-2$, $B C L-X$ and $B A X$ genes plays an essential role (Tilly et al. 1997, Kim \& Tilly 2004). This gene set works as a rheostat in which the balance between pro-apoptotic BAX and BCL- $X_{S}$ and anti-apoptotic BCL-2 and BCL-X proteins determines death or survival of the germ cell (Boise et al. 1993, Oltvai et al. 1993, Tilly et al. 1997). As a general rule, it has been observed that the expression of $B A X$ is normally enhanced, while BCL-2 protein is found at constitutive levels (Tilly et al. 1997).

It has been widely accepted that massive ovarian atresia is a general feature of the dynamics of 
mammalian female germ cell formation that, from an evolutionary perspective, might represent an extreme quality control selection process to maximize the chances of reproductive success (Tilly 2001). In most mammals, the production of oocytes in each reproductive cycle is adjusted to litter size, so ovulation rates correlate well with the number of embryos gestated to term. However, some mammals have been found to display natural polyovulation (Van der Horst \& Gillman 1941, Tripp 1971, Weir 1971a,b, Nicoll \& Racey 1985). These animals produce a large number of oocytes in each cycle, widely exceeding the effective number of gestated embryos and litter size at birth.

The South American plains viscacha, Lagostomus maximus, is a caviomorph rodent belonging to the suborder Hystricognatha displaying the highest ovulation rate described for a mammal. These females ovulate between 400 and 800 oocytes in each cycle and show extensive formation of corpora lutea, with a considerable number of oocytes lost before ovulation by luteinisation of the follicle (Weir 1971b). Consequently, oocyte loss in each oestrous may exceed a 1000 germ cells, taking account of ovulation and luteinisation rates (Weir 1971b).

Despite the extreme polyovulation displayed by L. maximus, a few, eight to ten oocytes, seem to be fertilized, and only one or two embryos are gestated to term (Weir 1971b). The high ovulation rate has been mainly explained as a consequence of the small size of the ovulatory follicle and the greatly convoluted anatomy of the ovary that increases the surface for ovulation (Weir 1971b).

In addition to the pioneer works performed by Weir $(1971 a, b)$, no other studies describing ovarian follicular atresia in L. maximus were reported as far as we could track in the literature. In this study, we tested the hypothesis that massive polyovulation in L. maximus arises from a natural downregulation of the apoptotic pathways that precludes follicular atresia and promotes a continuous oocyte production and the highest ovulation level recorded for a mammal.

\section{Materials and Methods}

\section{Animals and tissue collection and processing}

Adult ( $>2 \mathrm{~kg}$ ) plains viscachas, L. maximus, were trapped from the natural population of the Estación de Cría de Animales Silvestres (ECAS), Ministry of Agriculture, Villa Elisa, Buenos Aires province, Argentina. The research protocol was reviewed and approved by the Ethics and Research Committee of Universidad Maimónides. Handling and killing of captured animals were performed in accordance with the CCAC Guide for the Care and Use of laboratory Animals (CCAC 2002). A total of 21 adult females were captured during the breeding season in May-September 2004, including eight pregnant females, and 13 non-pregnant females among which three were lactating. In all cases, ovaries were collected and processed regardless of the oestrus cycle stage. Animals were anaesthetized with ketamine and immediately killed. The ovaries were removed and fixed in cold $4 \%$ neutral-buffered para- formaldehyde (PFA) for $24 \mathrm{~h}$. In some cases, one ovary was immediately frozen and preserved at $-75^{\circ} \mathrm{C}$ until processed for protein extraction (see below). After fixation in 4\% PFA, tissues were dehydrated through a graded series of ethanol and embedded in paraffin. Paraffin-embedded ovaries were serially sectioned at $5 \mu \mathrm{m}$, and mounted onto cleaned coated slides. Sections were dewaxed in xylenes (Sigma-Aldrich), and re-hydrated through a decreasing series of ethanol. Some sections from each specimen were stained with haematoxylin-eosin for general inspection and the remaining were stored until used for immunostaining or TUNEL assay.

\section{TUNEL assay}

Detection of DNA fragmentation/integrity was performed in paraffin-embedded sections by terminal deoxynucleotidyl transferase-mediated deoxyuridinetriphosphate nick end-labelling technique, using the 'In situ Cell Death Detection Kit' (Roche Diagnostics) with fluorescein-tagged nucleotides following suppliers' recommended procedure. Treated sections were examined in an Olympus BX40 microscope by conventional epifluorescence with u.v. illumination. In order to confirm negative results, TUNEL-processed sections were incubated with $10 \mathrm{UI} / \mathrm{ml}$ DNase II (Sigma Chemical Co.) in $50 \mathrm{mM}$ Tris-HCL pH 7.5, $10 \mathrm{mM} \mathrm{Mg} \mathrm{Ml}_{2}$ and $1 \mathrm{mg} / \mathrm{ml}$ BSA for $10 \mathrm{~min}$ at room temperature. After incubation, slides were thoroughly rinsed and treated again according to the TUNEL protocol. Images were captured with an Olympus Camedia C-5060 camera.

\section{Immunohistochemistry}

Dewaxed and re-hydrated ovarian sections were quenched in $3 \% \mathrm{H}_{2} \mathrm{O}_{2}$, blocked and incubated overnight at $4{ }^{\circ} \mathrm{C}$ with rabbit polyclonal anti-BAX and anti-BCL-2 primary antibodies (Santa Cruz Biotechnology, Santa Cruz, CA, USA). Polyclonal antibodies employed for BCL2 and $B A X$ detection were reactive against human, mouse and rat proteins. Immunoenzymatic reactions were performed with horseradish peroxidase (HRP) or alkaline phosphatase-labelled polymers, revealed with 3, 3'-diaminobenzidine (DAB) and/or fast-red respectively. In some cases, double stainings were performed by using 'EnVision Doublestain System' (Dako Cytomation Carpenteria, CA, USA) according to the recommendations of the manufacturer. Polyclonal mouse primary antibodies specific for $\alpha$-oestrogen (Santa Cruz 
Biotechnology) and progesterone (Neomarkers, Fremont, CA, USA) receptors were used separately for immunohistochemical analysis with the 'LSAB 2 System' (Dako Cytomation) and revealed with HRP-DAB. Procedure was as per the suppliers' recommendations. All slides were counterstained with haematoxylin. Negative controls were performed by omitting the primary antibody.

\section{Western-blot analysis}

Protein extraction from ovaries preserved at $-75{ }^{\circ} \mathrm{C}$ was carried out on ice and protease inhibitors $(0.5 \mathrm{mM}$ PMSF, $0.025 \mathrm{mM} \mathrm{N}$-CBZ-L-phenylalanine chloromethyl ketone, $0.025 \mathrm{mM} N^{\prime}$-p-tosyl-lysine chloromethyl ketone and $0.025 \mathrm{mM}$ L-1-tosylamide-2-phenyl-ethylchloromethyl ketone) were added to buffers, where indicated, immediately before use. Ovaries were immersed in five volumes of lysis buffer $(20 \mathrm{mM}$ Tris$\mathrm{HCl}, \mathrm{pH} 8.0,137 \mathrm{mM} \mathrm{NaCl}, 1 \%$ Nonidet P-40 and $10 \%$ glycerol) supplemented with protease inhibitors for $20 \mathrm{~min}$ at $4{ }^{\circ} \mathrm{C}$. After incubation, samples were homogenized with a high-speed homogenizer, centrifuged at $10000 \mathrm{~g}$ for $10 \mathrm{~min}$ at $4{ }^{\circ} \mathrm{C}$ and the pellet was discarded. Protein content of the supernatant was determined with the Bradford assay (BioRad). Aliquots of proteins $(100 \mu \mathrm{g})$ were boiled for $5 \mathrm{~min}$, resolved by SDS-PAGE $(15 \%)$ at $25 \mathrm{~mA}$ for $1.5 \mathrm{~h}$ and transferred to nitrocellulose membranes in transfer buffer containing $20 \%$ methanol $(\mathrm{v} / \mathrm{v}), 0.19 \mathrm{M}$ glycine and $0.025 \mathrm{M}$ Tris-base (pH 8.3). For the blot detection, we used the Western Blot Kit (Zymed Laboratories, Inc., San Francisco, CA, USA) according to the manufacturer's instructions. Rabbit polyclonal anti-BAX (1:500) and anti-BCL-2 (1:500) were used as primary antibodies. Granulosa cell protein extract from eSG+leuprolide acetate-treated rats kindly provided by $\mathrm{Dr} F$ Parborell (Parborell et al. 2002) were used as positive control for BAX protein. Muscle protein extract was employed for BCL-2 positive control.

\section{Results}

\section{Ovarian anatomy and histology}

L. maximus showed a laterally flattened ovary (Fig. 1A) with a mean length of $15 \pm 1.63 \mathrm{~mm}$, mean width of $6.53 \pm 0.47 \mathrm{~mm}$, a $1.23 \pm 0.20 \mathrm{~mm}$ thickness and an average weight of $0.167 \pm 0.058$ and $0.146 \pm 0.048 \mathrm{~g}$, left and right respectively. The surface of the entire organ was greatly convoluted (Fig. 1B). Histological sections showed that invaginations involved both the germinal epithelium and the tunica albuginea and extended deep into the organ, making it difficult to distinguish a clearly limited medullar area (Fig. 1C). In general, the ovary of both pregnant and non-pregnant females was found to be very rich in cortical tissue,
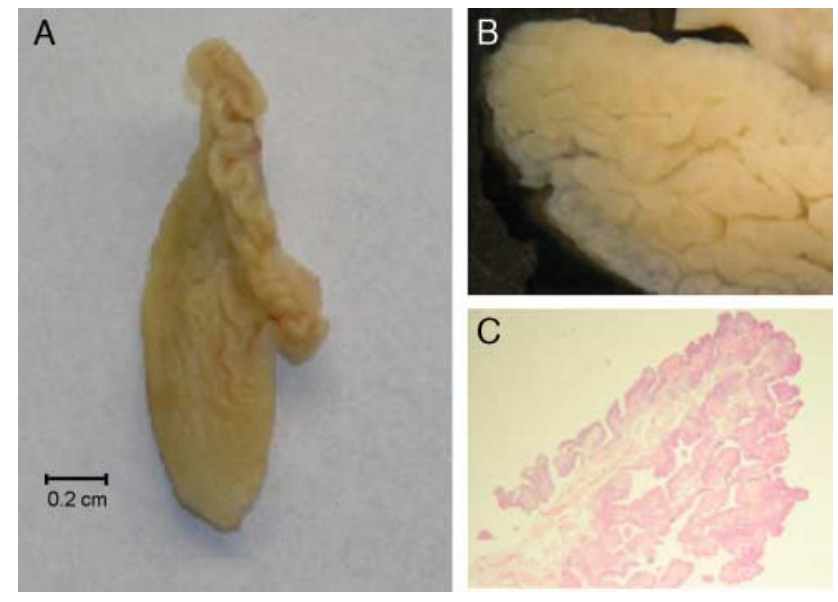

Figure 1 (A) General view of the mature ovary of the South American plains vizcacha, Lagostomus maximus. The surface of the organ (B) is greatly convoluted (C) with invaginations involving the tunica albuginea and extending deeply in the organ.

and abundantly packed with primordial follicles (Fig. 2A and B). All stages of folliculogenesis, from primordial to full mature antral follicles, were represented in every section inspected (Fig. 2D). Pregnant females also showed all follicular stages from primordial follicles to fully mature antral follicles. Classic staining revealed that fully mature atretic follicles are found very occasionally, both in gestating and non-gestating females (Fig. 2E). However, it is worth to note that atretic follicles were more frequent in pregnant females, although its detection was still low. Irrespective females being pregnant or not, corpora lutea were present in abundance too (Fig. 2C).

The general histological picture of $L$. maximus adult ovary reflected a continuous folliculogenesis. The high prevalence of primordial follicles resembled a typical late foetal and perinatal mammalian ovary.

\section{DNA integrity in follicles}

TUNEL analysis was conspicuously negative in histological ovarian sections from both pregnant and nonpregnant L. maximus females (Fig. $3 \mathrm{~A}, \mathrm{C}$ and D). The only TUNEL fluorescence detected was mostly associated with fully mature antral follicles (Fig. 3E), and correlated with occasional atretic follicles detected in haematoxylin-eosin stained sections. As a control for the specificity of the assay, negative sections were incubated with DNase II, and re-stained for TUNEL. All nuclei became TUNEL positive after DNase treatment (Fig. 3B, the same section as in Fig. 3A). Corpora lutea were also found negative both in pregnant and nonpregnant females, with isolated positive luteal cells detected occasionally. The whole corpus became positive after DNase treatment and re-staining for TUNEL. 

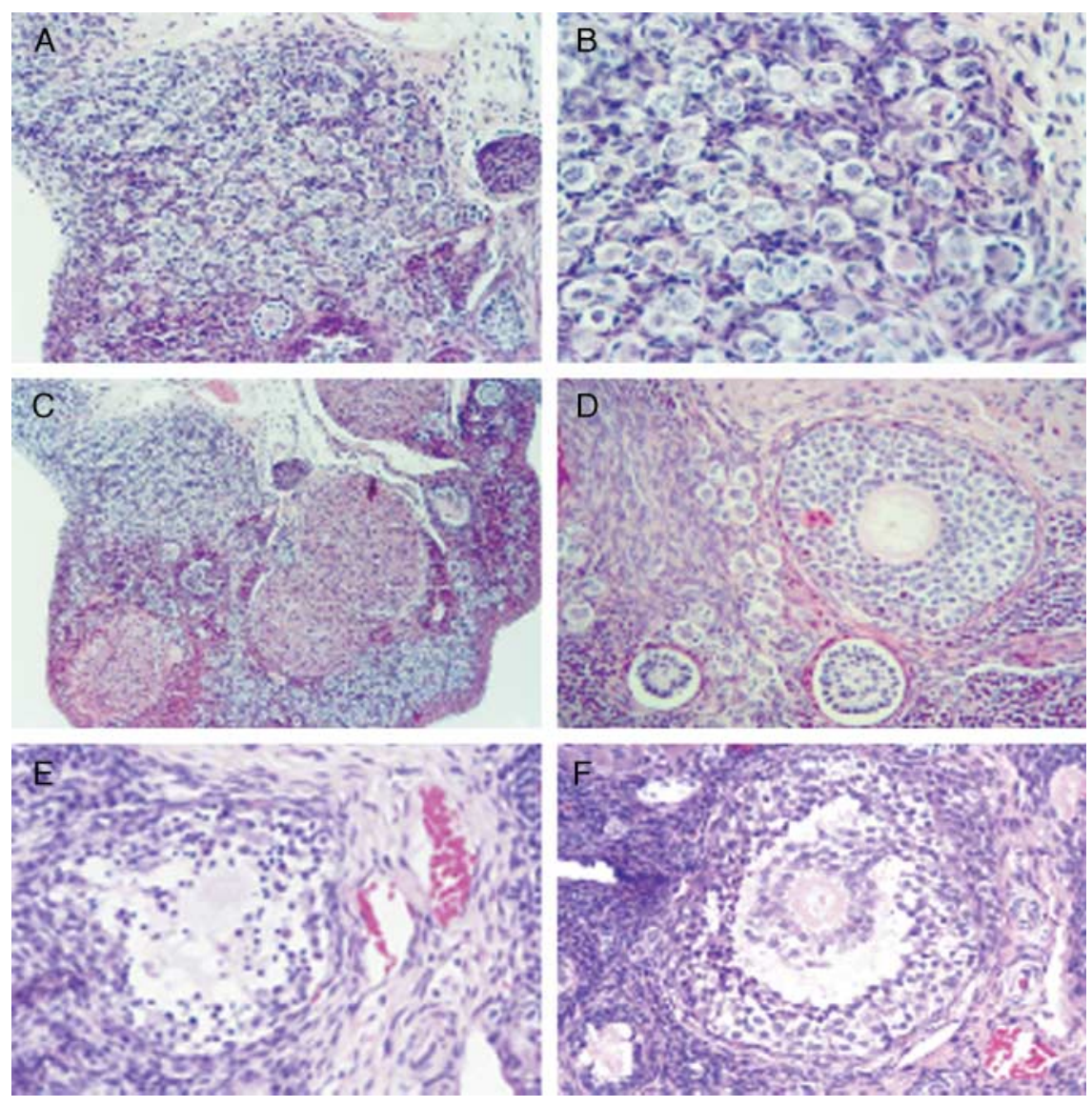

Figure 2 General histology of the adult ovary in L. maximus. (A) and (B) The ovary is abundantly packed with primordial follicles, (D) and all stages of folliculogenesis can be recognized both in pregnant and non-pregnant females. (C) Corpora lutea are also abundant. (F) Fully mature antral follicles are even present in gestating females. (E) Atretic follicles are rare.

\section{Immunohistochemistry and Western-blot analysis}

Anti-apoptotic BCL-2 protein showed a strong staining in all types of follicles from primordial to fully mature antral stages (Fig. 4). This marked expression of $B C L-2$ was found both in pregnant and non-pregnant females. Conversely, immunostaining for pro-apoptotic BAX protein revealed weak signals in some follicles or was undetectable at all (Fig. 4). In general, primordial follicles were BAX negative and when a signal was detected, it was restricted to preantral and antral follicles (Fig. 4). Conspicuous expression of BAX was only found in occasional atetric follicles.

Western analysis (Fig. 4) revealed the presence of immune-reactive proteins corresponding to $\mathrm{BCL}-2$ $(26 \mathrm{kDa})$ in extracts from $L$. maximus whole ovaries. The protein content for BCL-2 was comparable in all specimens $(n=7)$ analysed (Fig. $4 \mathrm{E})$. On the other hand, the same samples lacked detectable BAX (Fig. 4F). Protein profile by Western analysis for BCL-2 and BAX is consistent with immunohistochemistry results.

A high expression of $\alpha$-oestrogen receptor was revealed in all types of follicles (Fig. 5A-C) both in pregnant and non-pregnant females. Corpora lutea conspicuously expressed progesterone receptor even in non-gestating females (Fig. 5D-F).

\section{Discussion}

This study provides the first description of a mammal in which oocyte demise by follicular atresia in the adult ovary is abolished. Immunohistochemical and Western analysis showed that BCL-2 gene is markedly expressed in all type of follicles in the ovary of adult L. maximus, both in gestating and non-gestating individuals. Conversely, BAX protein is slightly detected in antral follicles or undetectable at all, especially in primordial follicles. These results are indicative of a natural inversion in the functioning of the $B C L-2 / B A X$ gene rheostat in the ovary of the plains viscacha, with an increased $B C L-2$ expression in the face of a restricted expression of $B A X$. It has been found, in general, that pro-apoptotic BAX protein has an enhanced expression in the mammalian ovary, while anti-apoptotic BCL-2 is expressed at constitutive levels (Rodger et al. 1995, Tilly et al. 1995, Rueda et al. 1997, Kim \& Tilly 2004). The balance between both proteins is responsible for the death or survival of the germ cells (Tilly et al. 1997, Kim \& Tilly 2004). Overexpression of BCL-2 precludes apoptosis as shown in transfection studies of cultured cells in which the protein protects cells from death, even if an apoptotic stimulus is applied to them (Reed 1994). 

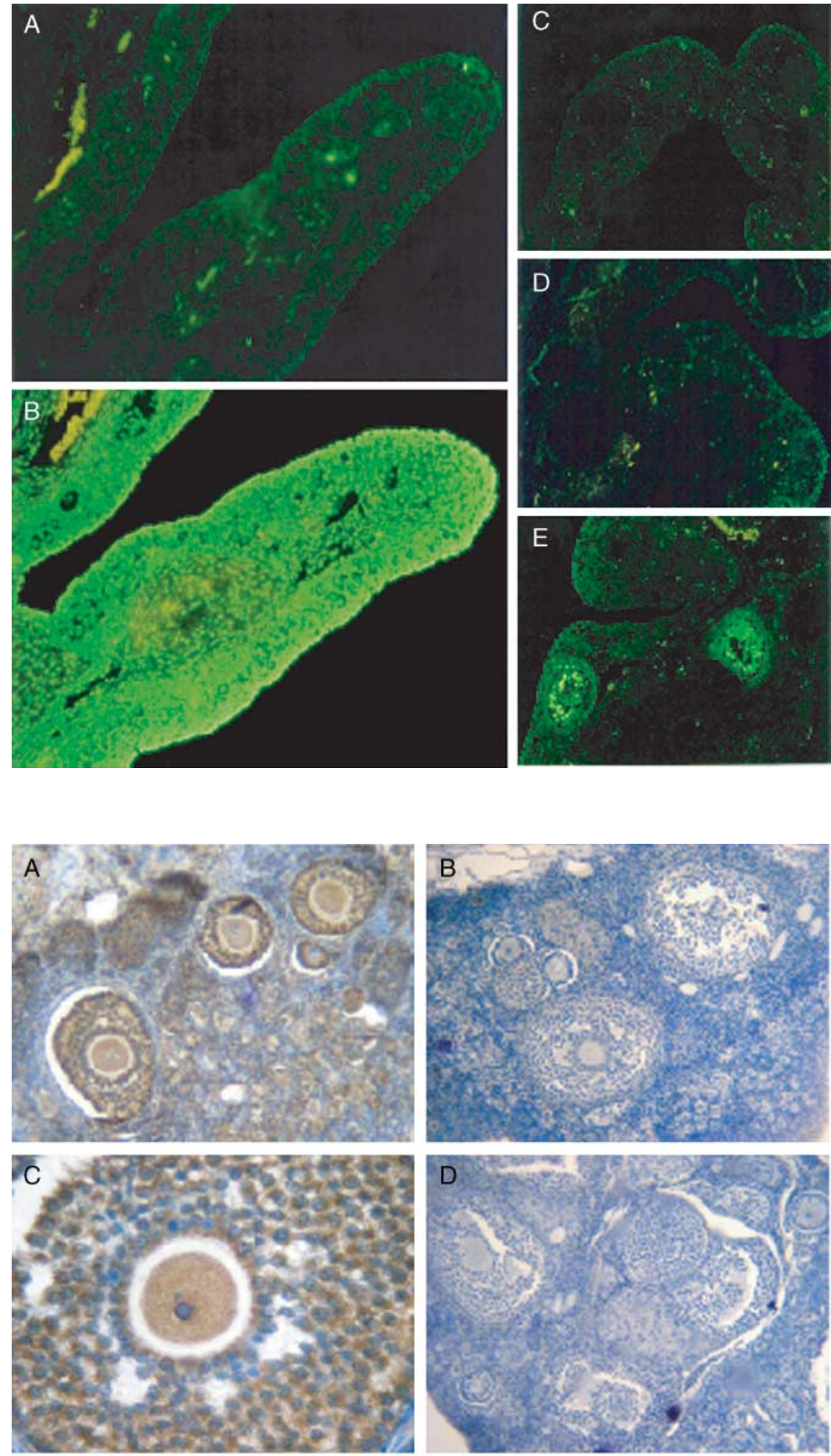

E

$\mathrm{F}$

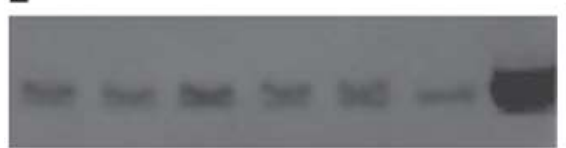

a

C

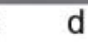

e $f$

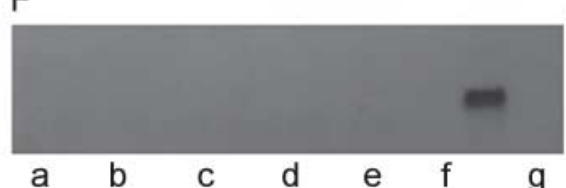

www.reproduction-online.org

Figure $4 B C L-2 / B A X$ expression balance in the adult ovary of L. maximus. (A) and (C) BCL-2 protein is conspicuously expressed in all kind of follicles from primordial to fully mature antral stages; (B) while BAX protein shows weak signals in preantral/antral follicles or is undetectable in primordial follicles. (D)

Negative control. (E) and (F) Western analysis in five representative ovarian samples (a-e); (E) $\mathrm{BCL}-2$ is detected at comparable amounts in all cases; (F) while BAX blots lacked detectable signals. Positive control for BAX ( $f$ ) and BCL-2 (g) was revealed as seen in $\mathrm{F}$ and $\mathrm{E}$ respectively (see Materials and Methods for details). 

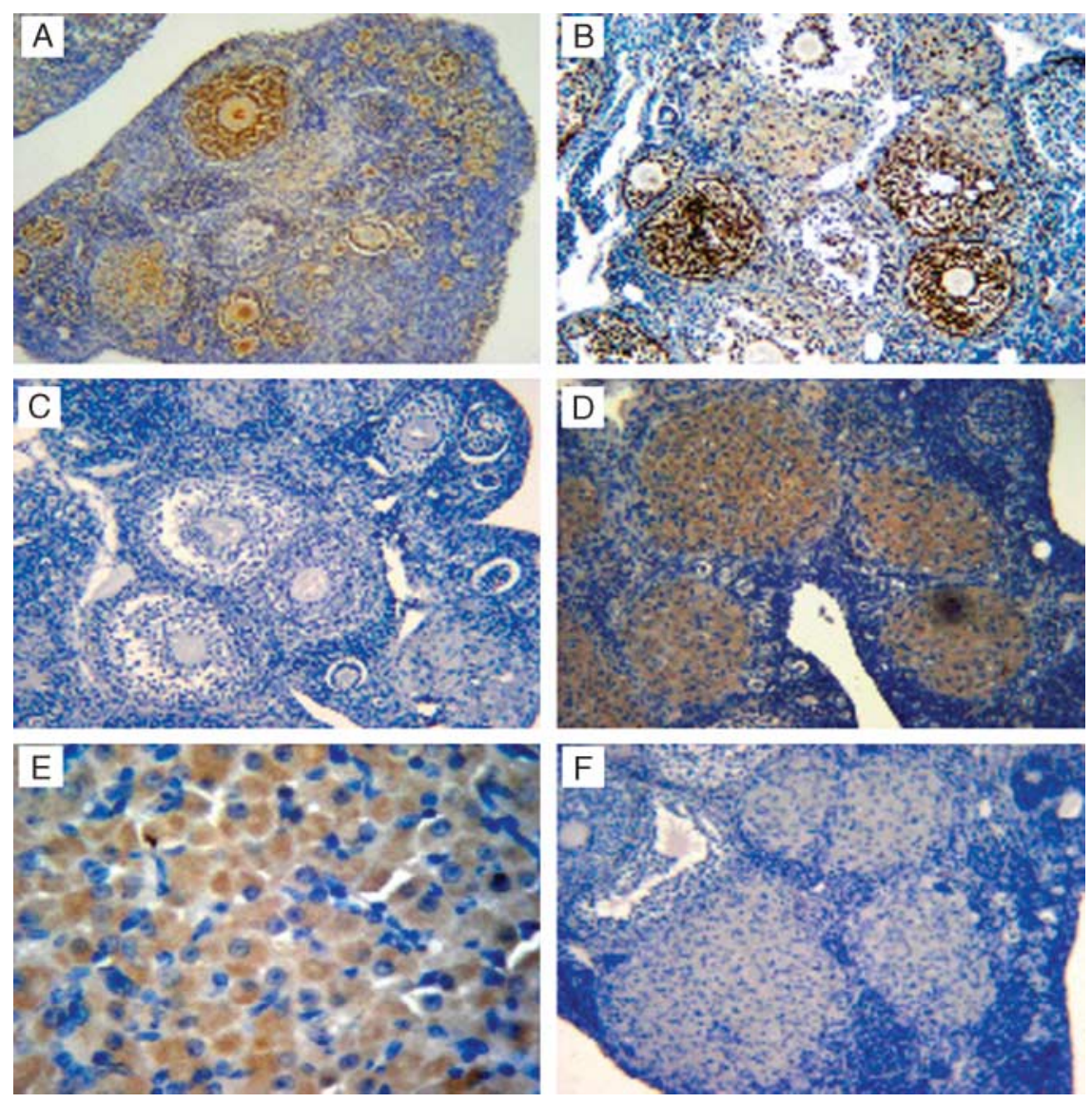

Figure 5 Immunolocalisation of $\alpha$-oestrogen $(\mathrm{ER})$ and progesterone (PR) receptors in the ovary of adult $L$. maximus. (A) and (B) ER is highly expressed in all kind of follicles and also in corpora lutea. (D) and (E) Detection of $\mathrm{PR}$ is conspicuous in corpora lutea, both in pregnant and non-pregnant females. (C) and (F) Negative controls.
Moreover, $B C L-2$ - and $B A X$-deficient knockout mice have decreased or increased primordial follicles respectively (Knudson et al. 1995, Ratts et al. 1995). Detection of BAX and BCL-2 proteins in the ovary of L. maximus indicates that expression of both genes is preserved in this species, and functional reversion of this gene rheostat prevents PCD. It is interesting to note that the pattern of enhanced $B C L-2$ expression found in $L$. maximus reminds that observed in many cancers where the protein not only contributes to tumour initiation, but also to uncontrolled proliferation and cell survival (Kirkin et al. 2004).

In line with $B C L-2$ overexpression and the scarce atretic follicles detected by standard haematoxylineosin staining, TUNEL analysis was remarkably negative in all the animals studied indicating a high degree of preservation of DNA integrity in germ cells.

Both BCL-2 overexpression and TUNEL results support the hypothesis that apoptosis is highly suppressed in the adult ovary of $L$. maximus. It is tempting to speculate that this suppression is responsible for sculpting the striking anatomy of the adult ovary of the plain viscacha. Our description of the ovary is in close agreement with the observation of Weir (1971b). Nonetheless, foetal ovary (Weir 1971b,
Jensen et al. 2005) and neonatal ovary (Weir 1971b) show a normal mammalian type of ovoid and solid organ. Invaginations of the germinal epithelium and the tunica albuginea through the cortex into the medulla began to appear at 6 weeks of age (Weir $1971 b)$. Preliminary observations in the foetal ovary seem to indicate that apoptosis is also highly suppressed during the conformation of the oocyte pool (Jensen et al. 2005). In this situation, exacerbated cell proliferation by overexpression of the antiapoptotic $B C L-2$ gene, may drive the invagination of the germinal epithelium in order to accommodate an unexpectedly large cell population.

Suppression of apoptosis and reduced atretic degeneration together with the high ovulatory rate found at each oestrous cycle indicate that follicle recruitment and selection may not be working as in other mammals. The high expression of oestrogen receptor we found supports the idea of an enhanced follicle survival and continuous folliculogenesis. Knockout mice for oestrogen receptors pointed out their essential role in preserving primordial follicles (Lubahn et al. 1993, Krege et al. 1998).

Another striking feature of the ovary of the plains viscacha is the abundance of corpora lutea as described by Weir $(1971 b)$. Corpora lutea are abundant both in 
gestating and non-gestating females and seem to be functional during the whole gestation period, since they continuously express progesterone receptor, do not show any sign of luteolgsis, and are conspicuously negative when screened for TUNEL. In addition, BCL-2 is also markedly expressed in luteal cells, while BAX protein displays a weaker signal or is not detected. It is interesting to note that the persistence of corpora lutea might reflect a placental hormonal defect, and be essential for continuous hormonal production.

For more than 50 years, it was accepted as a dogma of reproductive biology that mammalian females are born with a non-renewing, finite pool of oocytes that will be continuously cleared by atresia, with only a small proportion reaching ovulation, and no PGC persistence in the adult life (Pearl \& Schoppe 1921, Zuckerman 1951). The absence of persistence of PGC was recently questioned by the finding of a small PGC population in the ovary of adult laboratory mice (Johnson et al. 2004). Similarly, oocyte replenishing in adult life has also been observed in the mature ovaries from prosimian species of the genus Loris (David et al. 1974). Abolition of apoptosis and germ cell demise in $L$. maximus challenges the postulate of massive germ cell exhaustion through PCD in the mammalian ovary, contradicting too the decades-old tenet.

It is interesting to note that although oocyte reserve decline is not driven by follicular atresia and massive ovulation may account for it, the possibility that a continuous replenishing of the adult ovary may be active in L. maximus cannot be ruled out. As noticed by Weir $(1971 b)$, 'oocytes are still plentiful in the ovaries of animals known to have had at least seven ovulation periods'.

The dynamics of oocyte over production in L. maximus by suppressing apoptosis, the persistence of PGC in the adult mouse ovary (Johnson et al. 2004), and the detection of oogonial division and DNA synthesis in the ovaries of lorises (David et al. 1974) clearly indicate that mammals display more variability and strategies for oocyte production than previously thought.

\section{Acknowledgements}

The authors wish to specially thank the personnel of ECAS, Buenos Aires province, for their invaluable help in trapping the animals. Thanks to Dr Fernanda Parborell for providing positive extracts for BAX protein, Dr Paula Cameo for her advice in performing Western blots, and Ms Noelia Leopardo for her help in fieldwork. This project was funded by Universidad Maimónides, Argentina. Financial support provided by Horizontes ART, Río Negro, Argentina is specially acknowledged. The authors declare that there is no conflict of interest that would prejudice the impartiality of this scientific work.

\section{References}

Baker TG 1963 A quantitative and cytological study of germ cells in human ovaries. Proceedings of the Royal Society of London. Series B. Biological Sciences 158 417-433.

Boise LH, González-Garcia M, Postema CE, Ding L, Lindsten T, Turka LA, Mao X, Nunez G \& Thompson CB 1993 bcl-x, a bcl-2 related gene that functions as a dominant regulator of apoptotic cell death. Cell $\mathbf{4}$ 597-608.

CCAC 2002 Guía para el cuidado y uso de animals de laboratorio. National Academy Press. Mexican edition.

David GFX, Anand Kumar TC \& Baker TG 1974 Uptake of tritiated thymidine by primordial germinal cells in the ovaries of the adult slender loris. Journal of Reproduction and Fertility 41 447-451.

Flaws JA, Hirshfield AN, Hewitt JA, Babus JK \& Furth PA 2001 Effect of $\mathrm{BCl}-2$ on the primordial follicle endowment in the mouse ovary. Biology of Reproduction 64 1153-1159.

Forabosco A, Sforza C, De Pol A, Vizzotto L, Marzona L \& Ferrario VL 1991 Morphometric study of the human neonatal ovary. Anatomical Record 231 201-208.

Hirschfield AN 1991 Development of follicles in the mammalian ovary. International Review of Cytology 121 43-101.

Hsueh AJW, Eisenhauer K, Chun SY, Hsu SY \& Billig H 1996 Gonadal cell apoptosis. Recent Progress in Hormone Research 51 433-455.

Jensen F, Leopardo N, Espinosa MB \& Vitullo AD 2005 Inhibición de la apoptosis en el ovario fetal de Lagostomus maximus. Medicina (Buenos Aires) 65 (Suppl. II) 125.

Johnson J, Canning J, Kaneko T, Pru JK \& Tilly JL 2004 Germline stem cells and follicular renewal in the postnatal mammalian ovary. Nature 428 145-150.

Kaipia A \& Hsueh AJW 1997 Regulation of ovarian follicle atresia. Annual Review of Physiology 59 349-363.

Kim MR \& Tilly JL 2004 Current concepts in Bcl-2 family member regulation of female germ cell development and survival. Biochemistry and Biophysics Acta 1644 205-210.

Kirkin V, Joos S \& Zörnis M 2004 The role of Bcl-2 family members in tumorigenesis. Biochemistry and Biophysics Acta 1664 229-249.

Knudson CM, Tung KSK, Tourtellotte WG, Brown GAJ \& Korsmeyer SJ 1995 Bax-defiecient mice with lymphoid hyperplasia and male germ cell death. Science 270 96-99.

Krege JH, Hodgin JB, Couse JF, Enmark E, Warner M, Mahler JF, Sar M, Korach KS, Gustafsson JA \& Oliver S 1998 Generation and reproductive phenotypes of mice lacking estrogen receptor. PNAS 95 15677-15682.

Lubhan DB, Moyer JS, Golding TS, Couse JF, Korach KS \& Smithies O 1993 Alteration of reproductive function but not prenatal sexual development after insertional disruption of the mouse estrogen receptor gene. PNAS 90 11162-11166.

Nicoll ME \& Racey PA 1985 Follicular development, ovulation, fertilization and foetal development in tenrecs (Tenrec eucaudatus). Journal of Reproduction and Fertility 74 47-55.

Oltvai ZN, Milliman CL \& Korsmeyer SJ 1993 Bcl-2 heterodimerizes in vivo with a conserved homolog, Bax, that accelerates programmed cell death. Cell 74 609-619.

Parborell F, Pecci A, Gonzalez O, Vitale A \& Tesone M 2002 Effects of a gonadotropine-releasing hormone agonista on rat ovarian follicle apoptosis: Regulation by epidermal growth factor and the expresión of Bcl-2-related genes. Biology of Reproduction 67 481-486.

Pearl R \& Schoppe WF 1921 Studies on the physiology of reproduction in the domestic fowl. Journal of Experimental Zoology 34 101-118.

Ratts VS, Flaws JA, Kolp R, Sorenson CM \& Tilly JL 1995 Ablation of $b c l-2$ gene expression decreases the numbers of oocytes and primordial follicles established in the post-natal female mouse gonad. Endocrinology 136 3665-3668.

Reed JC $1994 \mathrm{BCl}-2$ and the regulation of programmed cell death. Journal of Cell Biology 124 1-6. 
Rodger FE, Fraser HM, Duncan WC \& Illinworth PJ 1995 Immunolocalization of $\mathrm{Bcl}-2$ in the human corpus luteum. Human Reproduction 10 1566-1570.

Rueda BR, Tilly KI, Botros I, Jolly PD, Hansen TR, Hoyer PB \& Tilly JL 1997 Increased bax and interleukin-1 $\beta$-converting enzyme (Ice) messenger RNA levels coincide with apoptosis in the bovine corpus luteum during structural regression. Biology of Reproduction $\mathbf{5 6}$ 186-193.

Tilly JL 1996 Apoptosis and ovarian function. Reviews of Reproduction 1 162-172.

Tilly JL 2001 Commuting the death sentence: How oocytes strive to survive. Nature Reviews 2 838-848.

Tilly JL, Tilly KI, Kenton ML \& Johnson AL 1995 Expression of members of the $b c l-2$ gene family in the immature rat ovary: equine chorionic gonadotropin-mediated inhibition of apoptosis is associated with decreased bax and constitutive $b c l-2$ and bcl-2 $2_{\text {long }}$ messenger ribonucleic acid levels. Endocrinology 136 232-241.

Tilly JL, Tillly KI \& Perez GI 1997 The genes of cell death and cellular susceptibility to apoptosis in the ovary: A hypothesis. Cell Death and Differentiation 4 180-187.
Tripp HR 1971 Reproduction in elephant-shrews (Macroselididae) with special reference to ovulation and implantation. Journal of Reproduction and Fertility 26 149-159.

Van der Horst CJ \& Gillman J 1941 The numbers of eggs and surviving embryos in Elephantulus. Anatomical Record 80 443-446.

Weir BJ 1971a The reproductive organs of the female plains viscacha, Lagostomus maximus. Journal of Reproduction and Fertility 25 365-373.

Weir BJ $1971 b$ The reproductive physiology of the plains viscacha, Lagostomus maximus. Journal of Reproduction and Fertility 25 355-363.

Zuckerman S 1951 The number of oocytes in the mature ovary. Recent Progress in Hormone Research 6 63-109.

Received 22 November 2005

First decision 14 February 2006

Revised manuscript received 26 April 2006

Accepted 16 May 2006 